Studia Kinanthropologica, XVII, 2016, (3), 157-163

The Scientific Journal for Kinanthropology

ROZSAH POHYBOVÝCH A ŠPORTOVYCH AKTIVÍT ŽIAKOV ZÁKLADNYCH ŠKÔL VO VOL̊NOM ČASE A MOTIVÁCIA K ICH VYKONÁVANIU

\title{
EXTENT OF PHYSICAL AND SPORT ACTIVITIES OF PRIMARY SCHOOL STUDENTS IN FREE TIME AND MOTIVATION TO ITS PER- FORMING
}

\author{
Š. Adamčák \& B. Beták \\ Univerzita Mateja Bela v Banskej Bystrici, Filozofická fakulta, Katedra telesnej výchovy a športu
}

\begin{abstract}
The aim of contribution is to present the results aimed on detection of physical and sport activities of primary school students in their free time and their motivation to its performing. Survey sample consisted of 437 students (197 girls and 240 boys) from seven primary school in selected villages and towns of eastern Slovakia. The main survey method was enquiry, which consisted of 15 questions. Enquiry was evaluated via TAP3 software by GAMO company from Banska Bystrica. The results of enquiry show that more than $45 \%$ of girls and boys perform physical activities during week in range of 1 to 3 hours a day and more than $45 \%$ of girls and boys in range of more than 6 hours a day during school year weekend. During holidays more than $59 \%$ of girls and boys perform physical activities in rang of 6 hours a day and more. Most frequently used place to perform physical activities for boys are sport facilities $(50.42 \%)$ and for girls it is their neighborhood (53.81\%). Both boys and girls main motivation to physical activities is their family, while the main reason to perform physical activities is for $43.65 \%$ of girls and $56.67 \%$ of boys the improvement of their health and physical fitness. As a main obstacle for not performing physical activities more than $38 \%$ of students stated poor availability of physical facilities in their neighborhood.
\end{abstract}

Keywords: motivation; physical and sport activities; free time; primary school; students

\section{SÚHRN}

Cielom príspevku je prezentovanie výsledkov prieskumu zameraného na zistenie rozsahu pohybových a športových aktivít žiakov základných škôl vo vol’nom čase a motivácia k ich vykonávaniu. Prieskumnú vzorku tvorilo 437 žiakov (197 dievčat a 240 chlapcov) siedmich základných škôl vo vybraných obciach a mestách východoslovenského kraja. Nosnou metódou bola anketa, ktorá pozostávala z 15 otázok. Anketa bola vyhodnocovaná prostredníctvom programu TAP3 firmy GAMO Banská Bystrica. Výsledky prieskumu poukazujú na skutočnoste, že viac ako $45 \%$ dievčat a chlapcov vykonáva počas pracovného týždňa pohybové aktivity v rozsahu 1 až 3 hodiny denne a viac ako $45 \%$ dievčat a chlapcov v rozsahu viac ako 6 hodín denne počas víkendu cez školský rok. Počas prázdnin viac ako 59 \% dievčat a chlapcov vykonáva pohybové aktivity v rozsahu viac ako 6 hodín denne. Najčastejším miestom vykonávania pohybových aktivít sú pre chlapcov športoviská $(50,42 \%)$ a pre dievčatá je to okolie ich bydliska $(53,81 \%)$. Obe pohlavia $\mathrm{k}$ pohybovej aktivite najviac motivuje rodina, pričom hlavný motív na vykonávanie pohybovej činnosti je pre 43,65 \% dievčat a 56,67 \% chlapcov zlepšenie a upevnenie svojho zdravia a telesnej zdatnosti. Ako hlavnú prekážku brániacu vykonávat pohybovú činnost' uviedlo viac ako $38 \%$ dievčat aj chlapcov slabú dostupnost priestorov v okolí bydliska.

Klúčové slová: motivácia; pohybové a športové aktivity; volný čas; základná škola; žiaci 


\section{Úvod}

Priemyselná revolúcia a neustále pokroky v informačno-komunikačných technológiách sa výrazne prejavujú v konzumnom spôsobe života mládeže. Dochádza k určitým zmenám v štruktúre záujmov a postojov mládeže, ktoré sa odzrkadlujú v prístupe k povinnostiam (škola, rodina), relaxu, obsahu a využitiu volného času (Nemcová, 2007). Volný čas je špecifická a dôležitá súčast života detí, mládeže a dospelých - človeka v každom veku (Kratochvílová, 2001). Je to čas na oddych, regeneráciu psychických a fyzických síl, na relaxáciu po skončení všetkých povinností, uspokojovanie potrieb a záujmov, priestor pre zábavu, rekreáciu, sebarealizáciu a vzdelávanie (Krystoň, 2003).

Volnočasové aktivity zohrávajú významnú úlohu v živote človeka. Ich spektrum je v živote mládeže mnohokrát pestré a široké a zahŕňa rôzne formy trávenia volného času. Jednou z foriem aktívneho trávenia volného času je pohybová aktivita. Junger \& Kasa (1996) definujú pohybovú aktivitu ako každú pohybovú činnoste, ktorá v dostatočnej miere zvyšuje požiadavky na funkcie organizmu, vyžadujúca energetický výdaj nad úroveň výdaja v pokoji. Zaradujú sem všetky pracovné činnosti, vrátane domácich prác, záujmové činnosti - záhradkárstvo, rybárstvo, polovníctvo, včelárstvo, rezbárstvo, zbieranie lesných plodov a liečivých rastlín, ako aj riadené telovýchovno-športové aktivity. Nemec \& Michal (2011) konštatujú, že pohybová aktivita je životnou funkciou každého z nás, či už ju vykonávame vo velkej alebo obmedzenej forme. Primeraný pohyb patrí popri vplyvoch životného prostredia, výžive, sociálnej interakcii a kultúrnych aspektov, k jedným z najdôležitejších aspektov životného štýlu človeka, dominantne mládeže.

\section{Metodika}

Prieskum bol realizovaný v rámci grantovej úlohy VEGA 1/0758/14 „Intervencia hravých aktivít na zmenu postojov žiakov k školskej telesnej výchove". Uskutočnil sa na siedmich vybraných základných školách v obciach a mestách východoslovenského kraja v I. polroku školskom roku 2015/2016 na žiakoch druhého stupňa. Skúmanú vzorku reprezentovalo 437 žiakov z toho 197 dievčat $(45,08 \%)$ a 240 chlapcov $(54,92 \%)$. Nosnou metódou použitou v našom prieskume bola opytovacia metóda konkrétne anonymná anketa, ktorá bola vytvorená na základe potrieb prieskumu. Anketa obsahovala 15 otázok. V príspevku uvádzame odpovede len na vybrané otázky. Na vyhodnotenie ankety sme využili program TAP veria 3 firmy Gamo Banská Bystrica.

Jednotlivé odpovede sme vyhodnocovali z pohladu intersexuálnych vztahov (dievčatá/chlapci). Pri spracovaní získaného faktografického materiálu sme použili matematicko-štatistické metódy (percentá, Chí-kvadrát), grafické metódy a kvalitatívne metódy.

\section{Výsledky a diskusia}

V prieskume nás dominantne zaujímalo kolko hodín zo svojho volného času venujú dievčatá a chlapci pohybovým aktivitám. Pod pojmom pohybová aktivita sme rozumeli akékolvek pracovné činnosti vrátane domácich prác, záujmové činnosti ako aj riadené telovýchovno-športové aktivity. Rozsah pohybových aktivít vo volnom čase dievčat a chlapcov sme zistovali počas školského roka (pracovný týždeň/víkend) a aj počas školských prázdnin. Zistenia kolko hodín zo svojho volného času vykonávajú dievčatá a chlapci pohybové aktivity počas pracovného týždňa cez školský rok prezentujeme na obrázku 1.

Z výsledkov vyplýva, že žiaci sa pohybovým a športovým aktivitám vo svojom volnom čase venujú. Dievčatá venujú vykonávaniu pohybových aktivít vo svojom volnom čase počas pracovného týždňa najčastejšie $1-3$ hodiny denne $(47,21 \%)$. Viac ako 3 hodiny denne počas pracovného týždňa sa pohybovej aktivite venuje 44,16 \% nami opýtaných dievčat. U chlapcov sme zaznamenali obdobné výsledky ako u dievčat, čo sa prejavilo aj na štatistickej nevýznamnosti rozdielov v odpovediach dievčat a chlapcov. Väčšna chlapcov $(45,83 \%)$ sa rovnako ako dievčatá vo svojom volnom čase venuje pohybovým aktivitám $1-3$ hodiny denne počas pracovného týždňa. Viac ako 3 hodiny denne počas pracovného týždňa sa pohybovým aktivitám venuje $43,33 \%$ chlapcov. Za pozitívne zistenie považujeme, že menej ako hodinu denne sa venuje pohybovým aktivitám len 8,63\% dievčat a 10,83\% chlapcov. Nízke percento pohybovej aktivity u mládeže prezentuje aj výskum Biddleho et al. (2009).

Časovú dotáciu, ktorú venuje mládež športovým aktivitám denne počas pracovného týždňa cez školský rok môže ovlyvňovat množstov faktorov. Či už je to množstvo školských povinností, navštevovanie rôznych záujmových krúžkov a podobne. Preto nás zaujímalo aj kolko hodín denne sa dievčatá a chlapci venujú pohybovej aktivte cez školský rok, ale počas víkendu. Pri vyhodnotení tejto otázky 
sme nezaznamenali signifikantné rozdiely v odpovediach dievčat a chlapcov. Výsledky prezentujeme na obrázku 2 .

Obrázok 1./ Figure 1.

Rozsah vykonávania pohybových aktivít dievčat a chlapcov denne vo volnom čase počas pracovného týždřa cez školský rok./ Range of performing physical activities of girls and boys daily in their free time during school week.

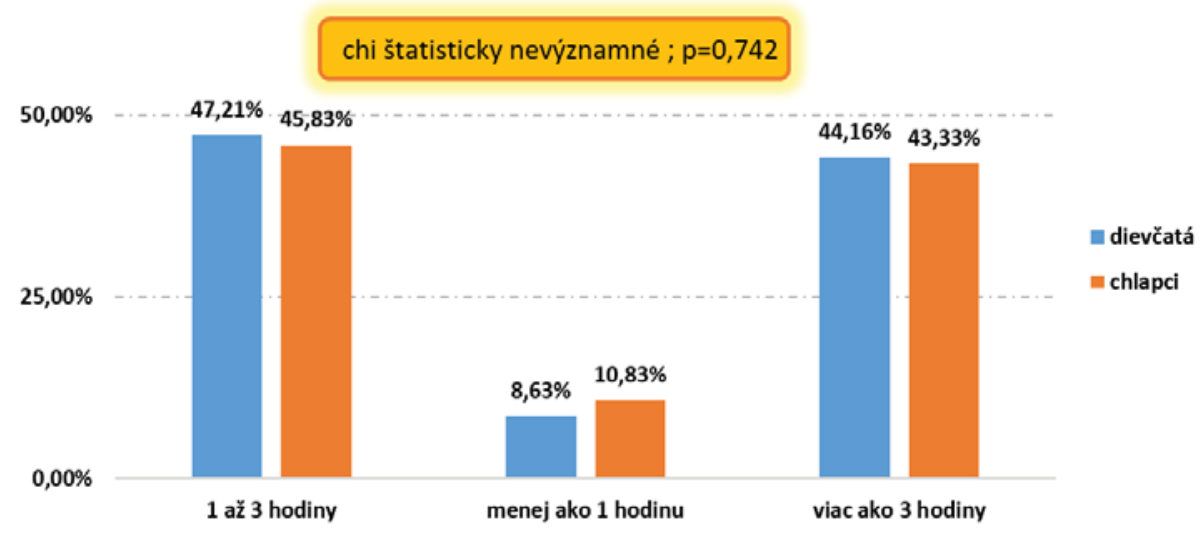

Dievčatá vykonávajú pohybové aktivity počas dní pracovného pokoja v najvačšej miere v rozsahu 3 až 6 hodín. Túto možnost zvolilo 46,70 \% dievčat základných škôl vo vybraných obciach a mestách východoslovenského kraja. Pozitívnym zistením je aj, že viac ako 45,69 \% dievčat vykonáva pohybové aktivity počas víkendov viac ako 6 hodín. Viac ako 6 hodín vykonáva pohybové aktivity počas víkendu aj takmer polovica opýtaných chlapcov (48,33\%) a 3 až 6 hodín venuje pohybovej aktivite 38,75\% chlapcov. Na základe týchto zistení konštatujeme, že naši respondenti sa venujú pohybovým aktivitám počas víkendu d’aleko viac ako cez týždeň.

Pri porovnaní našich zistení so zisteniam Nadera et al. (2008), ktorí vyskúmali, že deti vo veku 15 rokov vykonávajú pohybové aktvity len 49 minút za deň v týždni a počas víkendu je to ešte menej, iba 35 minút denne, považuje naše zistenia za pozitívne.

Obrázok 2./ Figure 2.

Rozsah vykonávania pohybových aktivít dievčat a chlapcov denne počas víkendu cez školský rok./ Range of performing physical activities of girls and boys daily during school weekend.

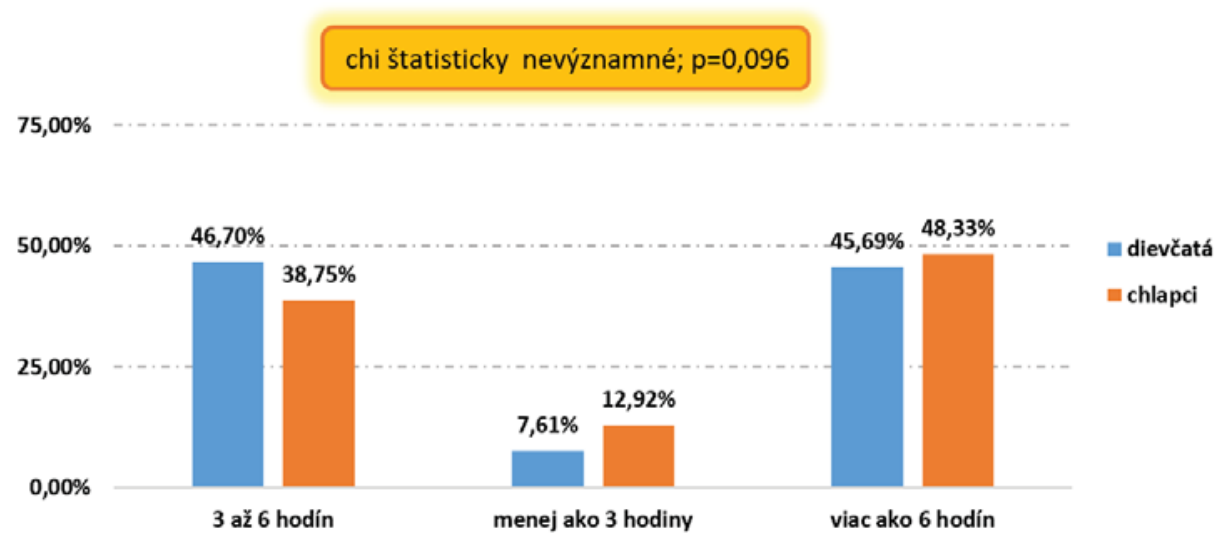

Prázdniny ponúkajú mládeži množstvo volného času. Ako ho mládež využije je výsostne individuálne. Preto nás v ankete zaujímalo, kolko času denne venujú vykonávaniu pohybových aktivít dievčatá a chlapci počas celého týždňa cez prázdniny (obrázok 3). 
Zo zistení prezentovaných na obrázku 3 vyplýva, že až 60,41 \% dievčat a až 59,58 \% chlapcov sa venuje pohybovým aktivitám počas prázdnin viac ako 6 hodín denne, čo je vel’mi pozitívne avšak prekvapivé zistenie. Rozsah vykonávania pohybových aktivít v intervale 3 - 6 hodín denne sme zaznamenali u 34,01 \% dievčat a 32,50 \% chlapcov. Pozitívnym zistením, je aj skutočnost, že len 5,58 \% dievčat a 7,92 \% chlapcov vykonáva pohybovú aktivitu menej ako 3 hodiny denne. Zaznamenané rozdiely v odpovediach dievčat a chlapcov neboli signifikatné.

To, že mládež využíva svoj volný čas počas prázdnin na vykonávanie pohybových aktivít môže mat̉ pozitívny vplyv na ich telesnú zdatnoste, na zlepšenie ich imunity a zvýšenie odolnosti voči chorobám.

Obrázok 3./ Figure 3.

Rozsah vykonávania pohybových aktivít dievčat a chlapcov denne počas celého týždňa cez prázdniny./ Range of performing physical activities of girls and boys daily during the whole week on holidays.

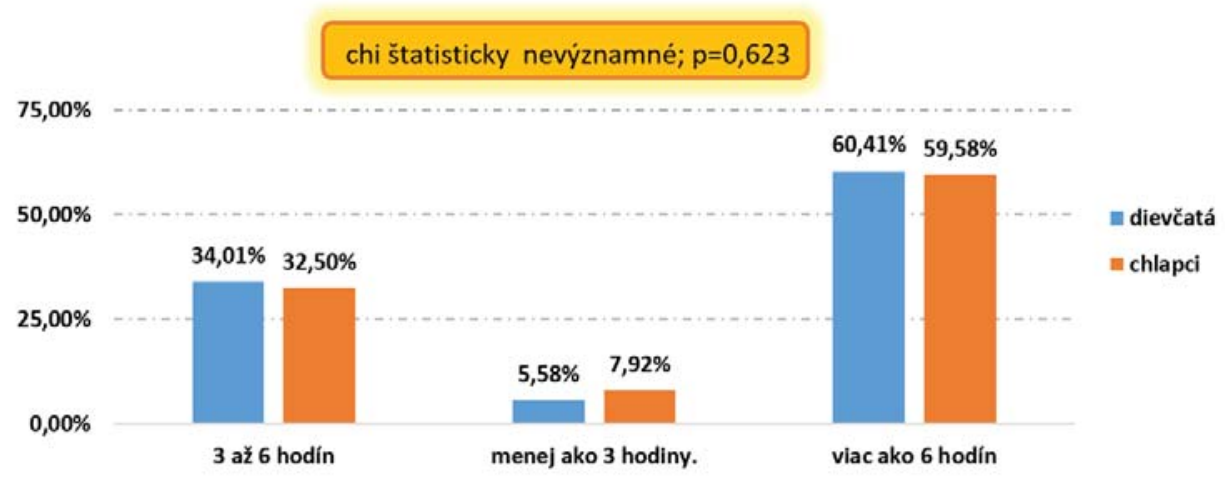

V d’alšej otázke sme zistoovali miesto, na ktorom dievčatá a chlapci vykonávajú pohybové aktivity najčastejšie. Dievčatá na vykonávanie pohybových aktivít dominantne využívajú prírodu v blízkosti svojho bydliska (dvor, ulica atd’.). Túto možnost zvolilo až 53,81 \% dievčat (obrázok 4). Ako druhé najčastejšie využívané miesto na pohybové aktivity uviedlo 44,16 \% dievčat športoviská. U chlapcov bolo poradie opačné. Na vykonávanie pohybových aktivít využíva viac ako polovica chlapcov $(50,42 \%)$ dominantne športoviská v podobe telocvične, posilňovne a ihriská a 38,75\% chlapcov prírodu v okolí bydliska. Z pohladu intersexuálnych rozdielov sme zaznamenali v odpovediach signifikatné rozdiely na hladine významnosti $\mathrm{p}<0,01$.

Obrázok 4./ Figure 4.

Miesto najčastejšieho vykonávania pohybových aktivit z pohladu dievčat a chlapcov./ Most frequent place of performing physical activities from the perspective of boys and girls.

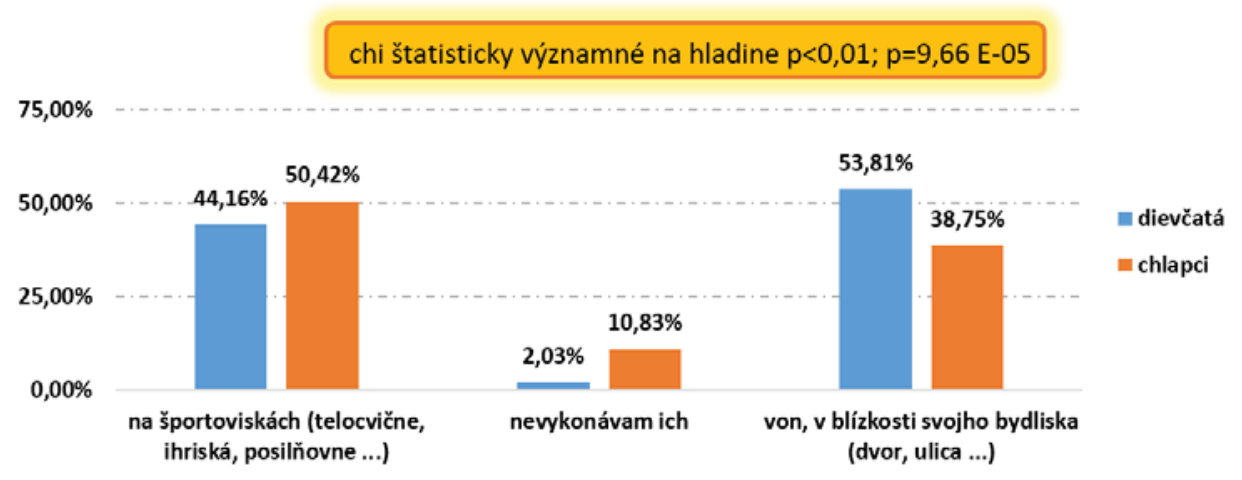

Osoba, ktorá podporuje a motivuje deti, resp. mládež k pohybovým aktivitám, je v živote človeka vel’mi dôležitá. Mnohokrát tým nevedomky pomáha k lepšiemu zdravotnému stavu, či fyzickej zdatnosti jedinca. Rychtecký \& Fialková (2004) konštatujú, že celková stimulácia rozvoja žiaka k pohybovým 
aktivitám sa uskutočňuje prostredníctvom širokého spektra overených pohybových aktivít, pôsobením školy, rodiny, spoločenských podmienok, ale aj pôsobením učitela telesnej a športovej výchovy.

Mnohé výskumy uvádzajú napr. Tajfel (1982), Moore et al. (1991), že najčastejšie je hlavným a nosným motivátorom potrieb dospievajúcej mládeže jeho vlastná rodina. Podobný názor zastávajú aj Pařízková et al. (2007), ktorí tvrdia, že ak diet̉a trávi vol’ný čas so svojimi rodičmi na prechádzke resp. pri rôznych športových aktivitách, je pre neho prirodzené, že si k pohybovej aktivite vytvorí pozitívny vzṫah. K tejto myšlienke sa prikláňame aj my.

Aj v našom prieskume nás zaujímalo, ktorá osoba motivuje najviac dievčatá a chlapcov $\mathrm{k}$ vykonávaniu pohybových aktivít (obrázok 5). U oboch pohlaví je to práve rodina, ktorá je hlavným motivátorom k pohybovej aktivite. K tejto možnosti sa priklonila viac ako polovica dievčat $(50,25 \%)$ aj chlapcov (53,33 \%). Vel’mi dôležitú úlohu pre mladého človeka zohráva rodinná anamnéza. Pokial' rodič alebo rodičia športujú zastávajú pre dieta nie len úlohu motivátora, ale aj úlohu pozitívneho vzoru. Obdobnú úlohu majú aj súrodenci, ktorí dokážu svojich bratov či sestry strhnút pre pohybové aktivity.

Po rodine uvádzajú dievčatá a chlapci ako významných motivátorov aj priatelov a kamarátov. Hlavne v období začleňovania sa dietała do kolektívy môžu kamaráti zohrat́ významnú rolu pri vytváraní vzţahu dietata k pohybovým aktivitám. Priatelia a kamaráti sú hlavnými motivátormi k pohybovej aktivite pre 31,98 \% dievčat a 32,50 \% nami opýtaných chlapcov. Najnižší podiel na motivácii dievčat a chlapcov pre pohybové aktivity má pre 17,77 \% dievčat a 14,17 \% chlapcov učitel' telesnej a športovej výchovy resp. tréner.

Z pohladu štatistickej významnosti neboli rozdiely medzi odpoved’ami dievčat a chlapcov signifikantné.

Obrázok 5./ Figure 5.

Osoba, ktorá najviac motivuje dievčatá a chlapcov $k$ pohybovej aktivite./ Person, who the most motivates girls and boys to physical activities.

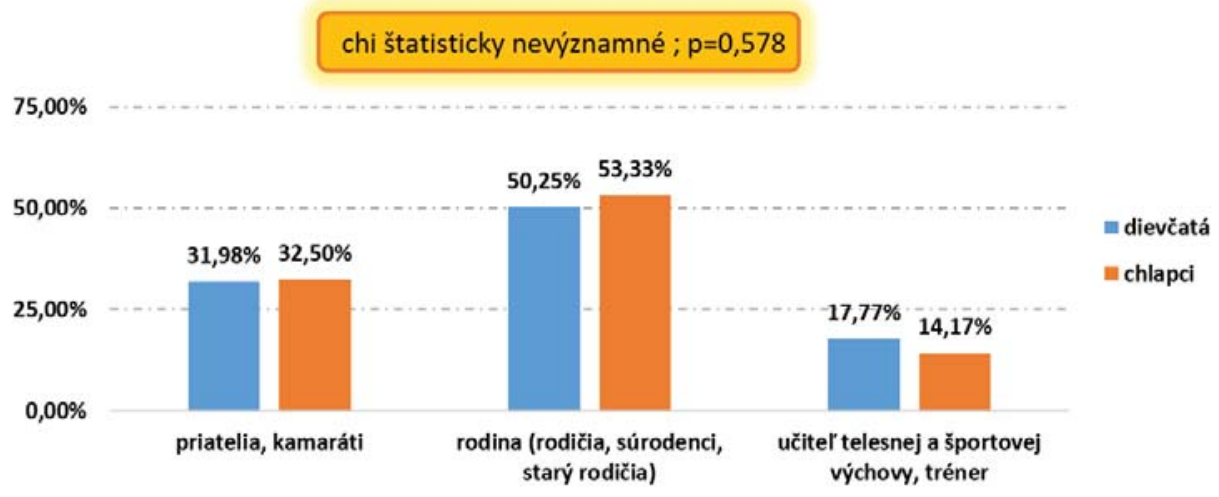

V prieskume nás tiež zaujímalo, aký je hlavný motív pre vykonávanie pohybových aktivít. Zistenia prezentujeme na obrázku 6 . Z troch ponúkaných možností zvolili obe pohlavia zlepšenie a upevnenie svojho zdravia a telesnej zdatnosti (43,65 \% dievčat a 57,67 \% chlapcov), čo hodnotíme vysoko pozitívne. Ako uvádza Nevolná (2013), pohybové aktivity vykonávané aktívne alebo len rekreačne majú pozitívny účinok nielen na telesné, ale aj na duševné zdravie každého človeka.

Zníženie svojej telesnej hmotnosti a zlepšenie postavy je dominantným motívom pre vykonávanie pohybových aktivít u 32,49 \% dievčat a 28,33 \% chlapcov. Oravcová (2004) uvádza, že telesný vzhl’ad je vel'mi dôležitou súčastou identity mladého človeka. Vzhlad býva často prostriedkom k dosiahnutiu sociálnej akceptácie a prestíže. U dievčat je to krása a atraktivita, ktorou môžu získat postavenie, alebo istú výhodu, len samotnou existenciou. U chlapcov je to fyzická sila, ktorá potvrdzuje sebestačnost', potláča neistotu a je prostriedkom, ktorým si môžu vydobyt rešpekt (Vágnerová, 2000).

Pre 23,86 \% dievčat a $15 \%$ chlapcov je dominantným motívom pre vykonávanie pohybových aktivít nadväzovanie spoločenských kontaktov a psychická relaxácia. Z pohladu štatistickej významnosti boli rozdiely v odpovediach dievčat a chlapcov signifikatné na hladine významnosti $\mathrm{p}<0,05$. 
Obrázok 6./ Figure 6.

Hlavný motív pre vykonávanie pohybových aktivít u dievčat a chlapcov./ Main reason for girls and boys performing physical activities.

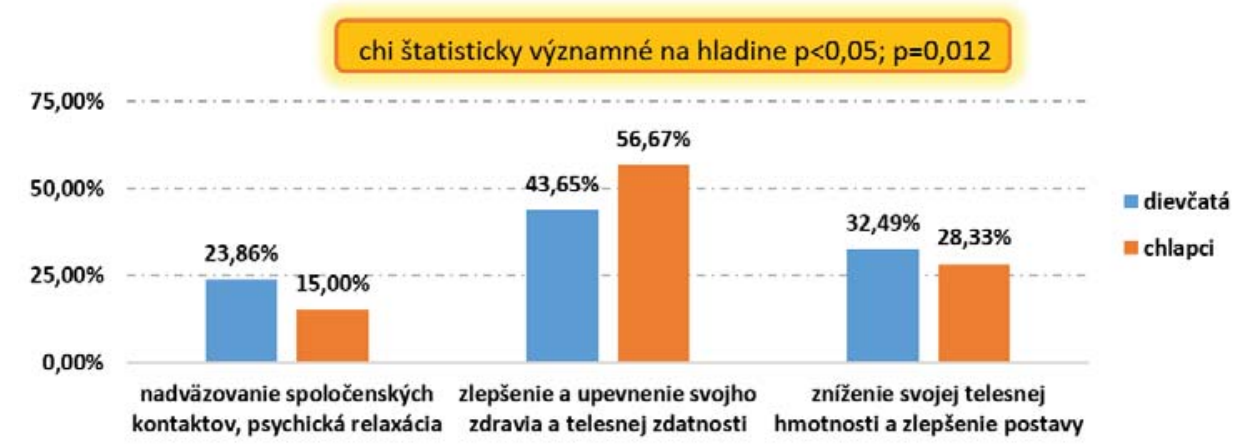

Nie je dôležité poznat len motívy pre vykonávanie pohybových aktivít, ale aj hlavné prekážky, ktoré mládeži bránia pohybové aktivity vykonávat. Pri vyhodnotení odpovedí dievčat a chlapcov sme pre tejto otázke nezaznamenali signifikatné diferencie.

Prieskumom sme zistili, že pre obe pohlavia je hlavnou prekážkou brániacou vykonávat̉ pohybové aktivity slabá dostupnost priestorov v blízkosti bydliska (obrázok 7). Túto možnost́ zvolilo 38,07 \% dievčat a 43,75 \% chlapcov. Na jednej strane je vhodných priestorov, prípadne športovísk na vykonávanie pohybových aktivít málo, no na druhej strane, pokial' má mládež o pohybovú aktivitu záujem, tak si priestory nájde. Zaujímavé zistenie prezentujú Reed \& Philips (2006), ktorí konštatujú, že pohybová aktivita mládeže je o to vyššia, čím je lepšia dostupnost’ priestorov na pohybovú aktivitu respektíve sú tie priestory dostatočne na pohybovo športovú aktivitu vybavené.

Druhou najčastejšie brániacou prekážkou vo vykonávaní pohybových aktivít boli pre dievčatá aj chlapcov zdravotné problémy respektíve iný spôsob trávenia volného času. Uviedla to takmer tretina dievčat a tretina chlapcov. Práve zdravotné problémy sú často uvádzaným dôvod brániacim k vykonávaniu pohybovej činnosti aj vo výskumoch iných autorov (Paugschová \& Kubaščík, 2002; Michal, 2007).

Vysokú finančnú náročnost̉ brániacu vykonávaniu pohybovej aktivity sme zaznamenali u 28,93 \% dievčat a 22,92 \% chlapcov. Títo respondenti mali na mysli prevažne športovú pohybovú aktivitu.

Obrázok 7./ Figure 7.

Hlavná prekážka brániaca vykonávat pohybovú aktivitu u dievčat a chlapcov./ Main obstacle preventing boys and girls in performing physical activities.

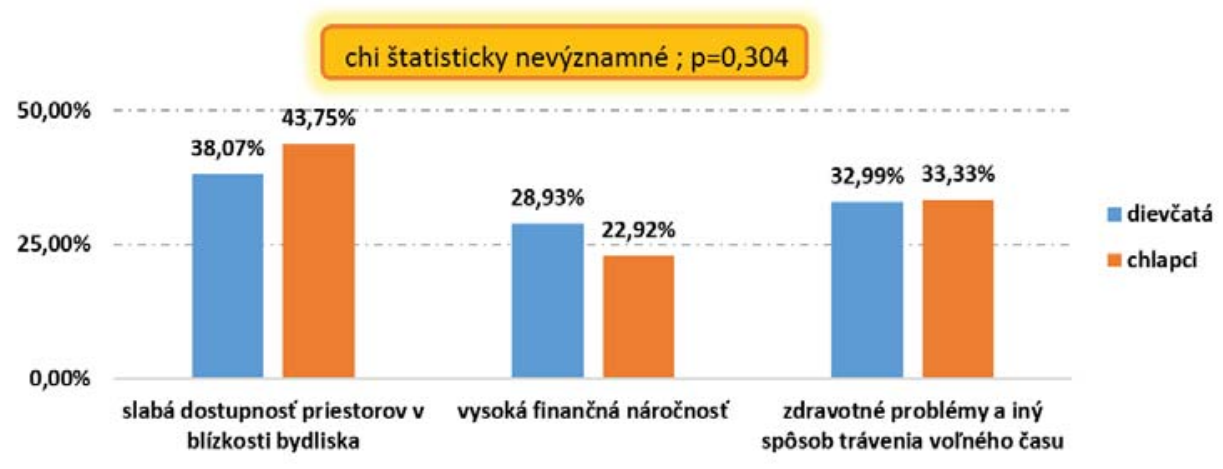

\section{Záver}

Na základe výsledkov prieskumu konštatujeme, že viac ako $45 \%$ dievčat a chlapcov vykonáva počas pracovného týždňa cez školský rok pohybové aktivity v rozsahu 1 až 3 hodiny denne. Počas víkendu 
sa venuje pohybovým aktivitám viac ako 6 hodín denne 45,69\% dievčat a 48,33\% chlapcov. Cez prázdniny viac ako $59 \%$ dievčat a chlapcov vykonáva pohybové aktivity v rozsahu viac ako 6 hodín denne. Zatial' čo pre 53,81\% dievčat je najčastejším miestom vykonávania pohybových aktivít okolie ich bydliska, tak pre 50,42 \% chlapcov sú to športoviská $(50,42 \%)$. Obe pohlavia k pohybovej aktivite najviac motivuje rodina, pričom hlavný motív na vykonávanie pohybovej činnosti je pre 43,65\% dievčat a 56,67 \% chlapcov zlepšenie a upevnenie svojho zdravia a telesnej zdatnosti. Slabú dostupnost’ priestorov v okolí bydliska označilo viac ako 38 \% dievčat aj chlapcov ako hlavnú prekážku brániacu vykonávat’ pohybovú činnost’

Vzhladom k súčasným negatívnym vývojovým trendom v našej spoločnosti voči zdraviu a pohybu, sme nepredpokladali takéto pozitívne výsledky v prospech pohybových a športových aktivít a ich realizácie vo volnom čase mládeže. Zistenie, že sa žiaci vo svojom volnom venujú pohybovým a športovým aktivitám považujeme za dôležité aj pre telovýchovný proces.

\section{Literatúra}

Biddle, S. J. H., Soos, I., Hamar, P., Sandor, I., Šimonek, J., Karsai, I., et al. (2009). Physical Activity and Sedentary Behaviours in Youth: Data from Three Central-Eastern European Countries. European Journal of Sport Science, 9(5), 295-301.

Junger, J. \& Kasa, J. (1996). Úvod do športovej kinantropológie. Prešov: Univerzita Pavla Jozefa Safárika v Košiciach, Pedagogická fakulta v Prešove.

Kratochvílová, E. (2001). Volný čas a pedagogika volného času. Vychovávatel', 45(5), 2-5.

Krystoň, M. (2003). Edukácia detí a mládeže vo volnom čase. Banská Bystrica: Univerzita Mateja Bela, Pedagogická fakulta.

Michal, J. (2007). Lyžovanie na druhom stupni základnej školy. Banská Bystrica: Univerzita Mateja Bela, Pedagogická fakulta.

Moore, L., Lombardi, D., White, M., Campbell, J., Oliveria, S., \& Ellison, C. (1991). Influence of parents'physical activity levels on activity levels of young children. Journal of Pediatrics, 118, 215-219.

Nader, P. R., Bradley, R. H., Houts, R. M., McRitchie, S. L., \& O’Brien, M. (2008). Moderate-tovigorous physical Activity From Ages 9 to 15 years. JAMA, 300(3), 295-305.

Nemcová, L. (2007). Výchova $k$ manželstvu a rodičovstvu v škole. Banská Bystrica: Univerzita Mateja Bela, Pedagogická fakulta, Občianske združenie Pedagóg.

Nemec, M. \& Michal, J. (2011). Analýza názorov na využívanie spindooru ako volnočasovej pohybovej aktivity. In J. Brodáni \& N. Halmová, (Eds.), Šport a zdravie: zborník vedeckých prác. Nitra: Pedagogická fakulta, Univerzita Konštantína Filozofa.

Nevolná, T. (2013). Záujmovo rekreačná telesná výchova ako účinný prostriedok k zdravému životnému štýlu. In Spolupracovníci kinantropológie a vedy. Brno: Masarykova univerzita Brno.

Oravcová, J. (2004). Vývinová psychológia: vysokoškolské učebné texty. Žilina: EDIS.

Pařízková, J., Lisá, L. et al. (2007). Obezita v dětství a dospivaní. Praha: Galén.

Paugschová, B., \& Kubaščík, R. (2002). Monitorovanie stavu lyžovania na základných školách Stredoslovenského regiónu. Banská Bystrica : Univerzita Mateja Bela, Fakulta humanitných vied.

Reed, J. A., \& Phillips, D. A. (2006). Relationship between physical activity and the proximity of exercise facilities and home exercise equipment used by undergraduate university students. Journal of American College Health, 53(6), 285-290.

Rychtecký, A., \& Fialová, L. (2004). Didaktika školní tělesné výchovy. Praha: Karolinum.

Tajfel, H. (1982). Social psychology of intergroup relations. Annual Review of Psychology, 33(1), 1-39.

Vágnerová, M. (2000). Vývojová psychologie: Dětství, dospělost, stáří. Praha: Portál.

doc. PaedDr. Štefan Adamčák, Ph.D.

Senická cesta 106

97401 Banská Bystrica

Slovenská republika

stefan.adamcak@umb.sk 